\title{
Immature stages and re-description of Henneguya suprabranchiae (Myxosporea: Myxobolidae), an intestinal parasite of the catfish Clarias gariepinus in the River Nile, Egypt
}

\author{
Amina El-Mansy* \\ National Institute of Oceanography and Fisheries (NIOF), 101 Kaser El-Einii Street, Cairo, Egypt
}

\begin{abstract}
A new morphological description, supported by light microscopy photographs, is presented for various immature stages and for mature Henneguya suprabranchiae Landsberg, 1987 spores infecting the intestine of the Nile catfish Clarias gariepinus, Burchell, 1822 (Syn.: C. lazera). Large cysts of 2 to $4.5 \mathrm{~mm}$ diameter, containing immature and mature stages, were present in the outer layer of the intestine. They caused severe damage to the smooth muscle and atrophy due to the increased size and resultant pressure of the plasmodial mass. From September 2000 to April 2001, 21 infected fishes were detected, with a parasite prevalence of $21.2 \%$. Nine immature stages were distinguished, and these have been measured, sketched and described. In addition, caudal process development was recorded. The mature spores are re-described and compared with previous descriptions of $H$. suprabranchiae spores. The main new morphological characteristics described are the number of polar filament coils, triangular thickening of the sporoplasm base, and a suture line visible only in lateral view.
\end{abstract}

KEY WORDS: Myxosporea $\cdot$ Henneguya suprabranchiae $\cdot$ Immature stages $\cdot$ Mature stages $\cdot$ Fish parasites $\cdot$ River Nile $\cdot$ Egypt

Resale or republication not permitted without written consent of the publisher

\section{INTRODUCTION}

Myxosporean parasites have received much attention in Africa and Egypt during the last decade. Investigators in various African countries have described about 100 myxosporean species from 9 genera, among them species from the genus Henneguya (Thelohan 1892, Paperna 1996, Fomena \& Bouix 1997). A great number of myxosporean species still need to be investigated. In African freshwater fishes, 12 species of the genus Henneguya have been described, including H. suprabranchiae, which was first described by Landsberg (1987) and subsequently by Ashmawy et al. (1989), Abdel-Ghaffar et al. (1995) and Hegazy (1999). All these studies described only 1 stage. The

*E-mail: el_mansy@hotmail.com present study provides a new description of the immature, pre-mature and re-description of mature spores in 10 stages.

The present study, describes morphological differentiation between juvenile (immature) and mature stages of Henneguya suprabranchiae spores, which will be useful for distinguishing between spores of related species, and re-describes the mature spores, introducing some new distinctive characteristics (number of polar filament coils, triangular thickening of the sporoplasm base, and a suture line). In addition, histopathological effects of the parasite on the intestine of the Nile catfish are described.

Henneguya species have been implicated as factors causing economic losses in catfish farms (McCraren et al. 1975) and tropical diseases in subtropical and ornamental fishes (Abolarin 1971, Paperna 1973, Shariff 1982, Kent \& Hoffman 1984). In addition, H. exilis 
causes serious mortality in mature catfish (Current \& Janovy 1978).

\section{MATERIALS AND METHODS}

The freshwater fish used in this study comprised 99 specimens of the catfish Clarias gariepinus Burchell, 1822 (synonym: C. lazera) of both sexes 33 to $36 \mathrm{~cm}$ in length and 244 to $279 \mathrm{~g}$ in weight. They were collected by trapping (beginning of September 2000 to end of April 2001) in the River Nile at Giza and the Cairo Governorates.

Immediately after collection, the fish were transported alive to the laboratory, where their length and weight were measured. They were then dissected and the intestine examined microscopically for myxosporean parasites under the stereo and light microscopes.

Different sporogonic stages were obtained from the cysts. An average of 45 spores was measured according to the methods recommended by Lom \& Arthur (1989). Permanent preparations were made by placing some spores in glycerol-gelatine and mounting under a cover slip. The structure of immature and mature stages was studied using a light microscope. In addition, air-dried smears were fixed in absolute methanol and stained with Giemsa. For histological examination, infected portions of the intestine were fixed in Bouin's solution, embedded in paraffin wax, cut in 4 to $5 \mu \mathrm{m}$ thick sections and stained with H\&E (Conn et al. 1960, Geoffrey \& Aimls 1978, Drury \& Wallington 1980).

\section{RESULTS}

Of the 99 catfish examined, 21 (21.2\%) were infected with Henneguya suprabranchiae. Within the plasmodia, immature stages dominated from September to January. Mature stages appeared in January and started to disappear by mid-April. They had com- pletely disappeared by the end of April. These parasites formed large cysts embedded along the outer layer of the intestine. The plasmodia were grayish and ovoid in shape and measured 2 to $4.5 \mathrm{~mm}$ in diameter.

\section{Immature stages (Figs. 1 to $10 \& 13$ to 27 )}

Nine immature stages were distinguished as a function of size and caudal process (tail) development (Table 1).

Stages 1 and 2. Disporic pansporoblasts within a cyst may be separated or may remain attached to each other until maturity. In both stages the spores are spherical, with 2 well-developed polar capsules. A very short polar filament is extruded. The spore body is surrounded by a very thin transparent membrane with a spherical small mass of sporoplasm cells. These stages do not possess a tail (Figs. 1, 2, 13, 14, 15 \& 17). In stage 2 an additional thin membrane surrounds the spore body (Figs. 3 \& 16).

Stage 3. The spore body is slightly elongated. Two additional cell-like structures are visible at the base of the sporoplasm (Figs. $3 \& 18$ ).

Stage 4. Spore size increases due to elongation and division of the 2 cells at their base (Figs. $3 \& 19$ ).

Stage 5. This stage differs in shape from previous stages due to further elongation of the 2 cells at the spore base. These cells develop into a thin, short tail and triangular thickening of the spore base. The spore body decreases in size (Figs. 4 \& 20).

Stages 6, 7 and 8. The tail is clearly visible and more developed. Polar capsules are similar in size to those at the fifth stage (Figs. $5 \& 21$ ). Spore size is larger (Figs. 7, 8 \& 22) and the tail is longer (Figs. 8 \& 23).

\section{Juvenile stage (Stage 9)}

Total spore length is $31.7 \mu \mathrm{m}$, the spore body is short, polar capsules are more developed, and polar capsule

Figs. 1 to 12. Henneguya suprabranchiae light microphotographs of fresh unfixed spores of immature and mature stages (host: Clarias gariepinus) $\times 1150$. Fig. 1. Stage 1, disporic pansporoblast within a cyst (arrow). Fig. 2 . Stage 1, free spherical spores with 2 well-developed polar capsules and mass of sporoplasm, the latter surrounded by a very thin transparent membrane (a). Two polar capsules seem to be oriented in opposite directions (b), short polar filament extrudes from a spore, and outer cyst is damaged (c). Fig. 3. Stages 3 to 5; in Stage 2, additional membrane is visible surrounding the spore body, and sporoplasm shape is more irregu$\overline{\operatorname{lar}(\mathrm{f}) ;}$ in Stage 3, 2 cells (arrow) are discernible at the base of the spore body (d); in Stage 4, elongation and division of 2 cells (arrow) are clearly visible (e). Fig. 4. Stage 5, characterized by very short tail (arrow) and 2 small polar capsules (g). Fig. 5. Stage 6, elongation of tail continues (h). Fig. 6. Spore body (arrow) is larger and ovoid in shape also sporoplasm is wider. Further elongation of the tail is clearly visible. Fig. $\overline{7}$. Shell opening (arrow) of sporulation stage (i). Fig. 8. Stage 8, showing separation of the symmetrical spore-shell valves (arrow) and further elongation of the spore body, sporoplasm and tail (j). Fig. 9 . Lateral view of Stage 9 (juvenile) stage: 1 polar capsule and a well-developed long tail are clearly visible (k). Fig. 10. Stage 9, showing characteristic body shape of the spore; polar filament coils are further developed and tail is long. Fig. 11. Stage 10, showing pansporoblast with 2 mature spores lying parallel to each other, 1 spore appears slightly longer than the other. Fig. 12. Stage 10, spore in anterior view (bottom spore) with completely developed polar filaments; triangular thickening (arrow) is complete; in top spore central iodinophilous vacuole is enclosed in the sporoplasm (arrow). Lateral view (l) shows protruding suture edge and suture line (arrow) 


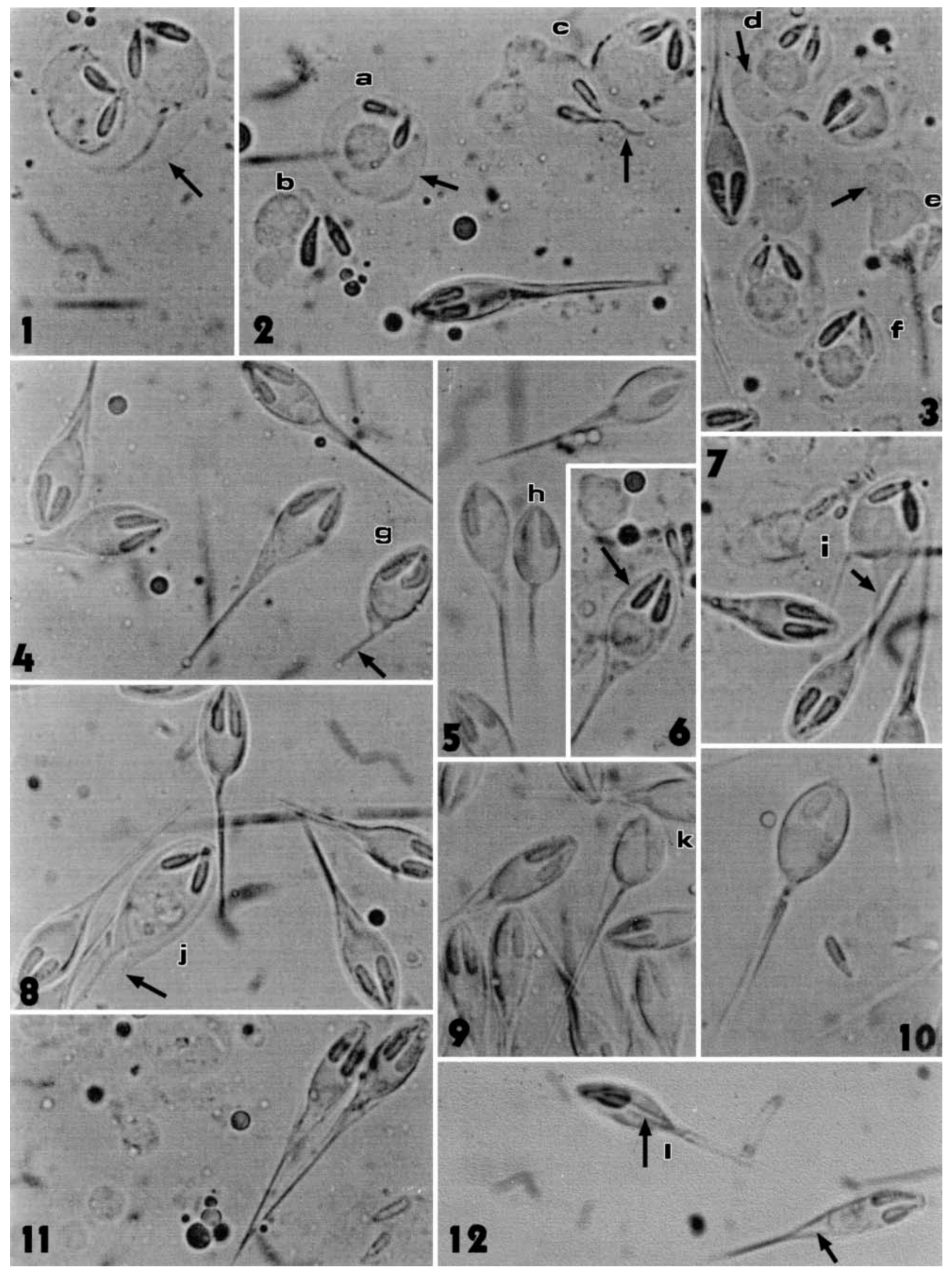


Table 1. Henneguya suprabranchiae. Measurements $(\mu \mathrm{m})$ of immature stages

\begin{tabular}{|c|c|c|c|c|c|c|}
\hline \multirow{2}{*}{$\begin{array}{l}\text { Stage } \\
\text { No. }\end{array}$} & \multicolumn{2}{|c|}{ Spore body } & \multicolumn{2}{|c|}{ Polar capsules } & \multirow{2}{*}{ Tail } & \multirow{2}{*}{$\begin{array}{l}\text { Total } \\
\text { length }\end{array}$} \\
\hline & Length & Width & Length & Width & & \\
\hline 1 & $\begin{array}{c}10.5 \\
(9.75-11.25)\end{array}$ & $\begin{array}{c}10.9 \\
(9.8-12)\end{array}$ & $\begin{array}{c}4.9 \\
(4.5-5.3)\end{array}$ & $\begin{array}{c}1.3 \\
(1.1-1.5)\end{array}$ & Absent & 10.5 \\
\hline 2 & $\begin{array}{c}12.4 \\
(12.0-12.8)\end{array}$ & $\begin{array}{c}11.7 \\
(10.5-12.8)\end{array}$ & $\begin{array}{c}5 \\
(3.75-6.0)\end{array}$ & $\begin{array}{c}1.1 \\
(0.75-1.5)\end{array}$ & Absent & 12.4 \\
\hline 3 & $\begin{array}{c}14.7 \\
(14.3-15.0)\end{array}$ & $\begin{array}{c}6.4 \\
(5.3-7.5)\end{array}$ & $\begin{array}{c}4.9 \\
(4.5-5.3)\end{array}$ & $\begin{array}{c}1.3 \\
(1.1-1.5)\end{array}$ & $\begin{array}{l}\text { Development begins with } 2 \\
\text { slightly elongated cells }(3.8 \mu \mathrm{m})\end{array}$ & 14.7 \\
\hline 4 & $\begin{array}{c}15.4 \\
(15.0-15.8)\end{array}$ & $\begin{array}{c}7.9 \\
(7.5-8.3)\end{array}$ & $\begin{array}{c}4.9 \\
(4.5-5.3)\end{array}$ & $\begin{array}{c}1.1 \\
(0.75-1.5)\end{array}$ & $\begin{array}{l}\text { Cell mass is more elongated } \\
\text { and divided }(4.5 \mu \mathrm{m})\end{array}$ & 15.4 \\
\hline 5 & $\begin{array}{c}10.2 \\
(9.8-10.5)\end{array}$ & $\begin{array}{c}5.7 \\
(5.3-6.0)\end{array}$ & $\begin{array}{c}4.9 \\
(4.5-5.3)\end{array}$ & $\begin{array}{c}1.7 \\
(1.5-1.9)\end{array}$ & $\begin{array}{l}\text { Thread-like short tail } \\
\text { visible }(7.5 \mu \mathrm{m})\end{array}$ & 17.3 \\
\hline 6 & $\begin{array}{c}8.8 \\
(8.6-9.0)\end{array}$ & $\begin{array}{c}5.1 \\
(4.9-5.3)\end{array}$ & $\begin{array}{c}4.7 \\
(4.1-5.3)\end{array}$ & $\begin{array}{c}1.7 \\
(1.5-1.9)\end{array}$ & $\begin{array}{l}\text { Tail more prominent } \\
\qquad(10.5 \mu \mathrm{m})\end{array}$ & 19.5 \\
\hline 7 & $\begin{array}{c}11.6 \\
(11.3-12.0)\end{array}$ & $\begin{array}{c}7.2 \\
(6.8-7.5)\end{array}$ & $\begin{array}{c}5.1 \\
(4.9-5.3)\end{array}$ & $\begin{array}{c}1.3 \\
(1.1-1.5)\end{array}$ & $\begin{array}{c}13.9 \\
(13.5-14.3)\end{array}$ & 25.5 \\
\hline 8 & $\begin{array}{c}14.7 \\
(14.3-15.1)\end{array}$ & $\begin{array}{c}7.8 \\
(7.5-8.3)\end{array}$ & $\begin{array}{c}4.9 \\
(4.5-5.3)\end{array}$ & $\begin{array}{c}1.3 \\
(1.1-1.5)\end{array}$ & $\begin{array}{c}14.7 \\
(14.3-15.0)\end{array}$ & 29.4 \\
\hline 9 & $\begin{array}{c}12.3 \\
(12.0-12.8)\end{array}$ & $\begin{array}{c}7.2 \\
(6.8-7.5)\end{array}$ & $\begin{array}{c}5.3 \\
(4.5-6.0)\end{array}$ & $\begin{array}{c}2.1 \\
(1.9-2.3)\end{array}$ & $\begin{array}{c}19.4 \\
(17.4-21.8)\end{array}$ & 31.7 \\
\hline
\end{tabular}

caps appear at the anterior end of the spore. The spore tail is longer than in the earlier stages (Figs. 9, 10, 24 \& 25).

\section{Mature spores (Stage 10)}

Mature spores were measured (Table 2) and are illustrated in Figs. 11, 12, 26, 27 \& 31. The mature spores are elongated in anterior view, with a pro- truding, rounded, anterior end. In lateral view, a suture line is visible (Fig. 12). Two thin and equal caudal processes extend from the posterior end of the spore. At the base of the sporoplasm a triangular thickening is fully developed (Fig. 12). The polar capsules are elongated and parallel, and are tapered, with a cap-like structure. The number of polar filament coils is 8 to 12 upon release. A few sporoplasms contain a rounded central, iodinophilous vacuole (Fig. 31).

Table 2. Henneguya suprabranchiae. Comparison of measurements (mm) of mature spores. (Stage 10 based on 126 spores) with those of morphologically similar species

\begin{tabular}{|c|c|c|c|c|c|}
\hline \multirow[t]{2}{*}{ Species } & \multicolumn{2}{|c|}{ Spore body } & \multicolumn{2}{|c|}{ Polar capsules } & \multirow{2}{*}{$\begin{array}{c}\text { Tail } \\
\text { (caudal process }\end{array}$} \\
\hline & Length & Width & Length & Width & \\
\hline $\begin{array}{l}\text { H. bopeleti } \\
\text { (Fomena \& Bouix 1987) }\end{array}$ & $\begin{array}{c}17.2 \\
(15.0-19.0)\end{array}$ & $\begin{array}{c}6.35 \\
(5.7-7.1)\end{array}$ & $\begin{array}{c}8.01 \\
(7.0-8.9)\end{array}$ & $\begin{array}{c}2.0 \\
(1.6-2.5)\end{array}$ & $\begin{array}{c}27.43 \\
(22.5-29.0)\end{array}$ \\
\hline $\begin{array}{l}\text { H. branchialis } \\
\text { (Ashmawy et al. 1989) }\end{array}$ & $\begin{array}{c}14.5 \\
(13.3-15.4)\end{array}$ & $\begin{array}{c}5.6 \\
(4.7-5.6)\end{array}$ & $\begin{array}{c}6.2 \\
(5.5-7.7)\end{array}$ & $\begin{array}{c}2.2 \\
(2.15-2.58)\end{array}$ & $\begin{array}{c}17.3 \\
(14.6-25.8)\end{array}$ \\
\hline $\begin{array}{l}\text { H. branchialis } \\
\text { (Abdel Ghaffar et al. 1995) }\end{array}$ & $\begin{array}{c}14.7 \\
(12.7-17.6)\end{array}$ & $\begin{array}{c}5.0 \\
(4.4-6.4)\end{array}$ & $\begin{array}{c}6.9 \\
(5.9-8.3)\end{array}$ & $\begin{array}{c}2.1 \\
(1.5-2.9)\end{array}$ & $\begin{array}{c}19.7 \\
(15.7-23.5)\end{array}$ \\
\hline $\begin{array}{l}\text { H. nyongersis } \\
\text { (Fomena \& Bouix 1996) }\end{array}$ & $\begin{array}{c}12.6 \\
(10.0-14.0)\end{array}$ & $\begin{array}{c}5.4 \\
(4.5-6.5)\end{array}$ & $\begin{array}{c}6.2 \\
(5.5-7.7)\end{array}$ & $\begin{array}{c}2.3 \\
(2.0-2.8)\end{array}$ & $\begin{array}{c}21 \\
(20.0-23.5)\end{array}$ \\
\hline $\begin{array}{l}\text { H. suprabranchiae } \\
\text { (Landsberg 1987) }\end{array}$ & $\begin{array}{c}13.5 \\
(12.2-14.3)\end{array}$ & $\begin{array}{c}6.4 \\
(5.6-6.9)\end{array}$ & $\begin{array}{c}7.6 \\
(7.0-8.1)\end{array}$ & $\begin{array}{c}2.1 \\
(1.8-2.3)\end{array}$ & $\begin{array}{c}24 \\
(18.5-29.0)\end{array}$ \\
\hline $\begin{array}{l}\text { H. suprabranchiae } \\
\text { (Hegazy 1999) }\end{array}$ & $\begin{array}{c}12.06 \\
(9.24-15.0)\end{array}$ & $\begin{array}{c}5.03 \\
(3.85-6.93)\end{array}$ & $\begin{array}{c}6.36 \\
(3.85-9.0)\end{array}$ & $\begin{array}{c}1.34 \\
(1.0-2.5)\end{array}$ & $\begin{array}{c}23.81 \\
(20.02-30.0)\end{array}$ \\
\hline $\begin{array}{l}\text { H. suprabranchiae } \\
\text { (present study; Stage 10) }\end{array}$ & $\begin{array}{c}12.4 \\
(12.1-12.7)\end{array}$ & $\begin{array}{c}5.3 \\
(4.5-6.0)\end{array}$ & $\begin{array}{c}5.7 \\
(5.3-6.0)\end{array}$ & $\begin{array}{c}1.3 \\
(1.1-1.5)\end{array}$ & $\begin{array}{c}23.7 \\
(22.9-24.4)\end{array}$ \\
\hline
\end{tabular}



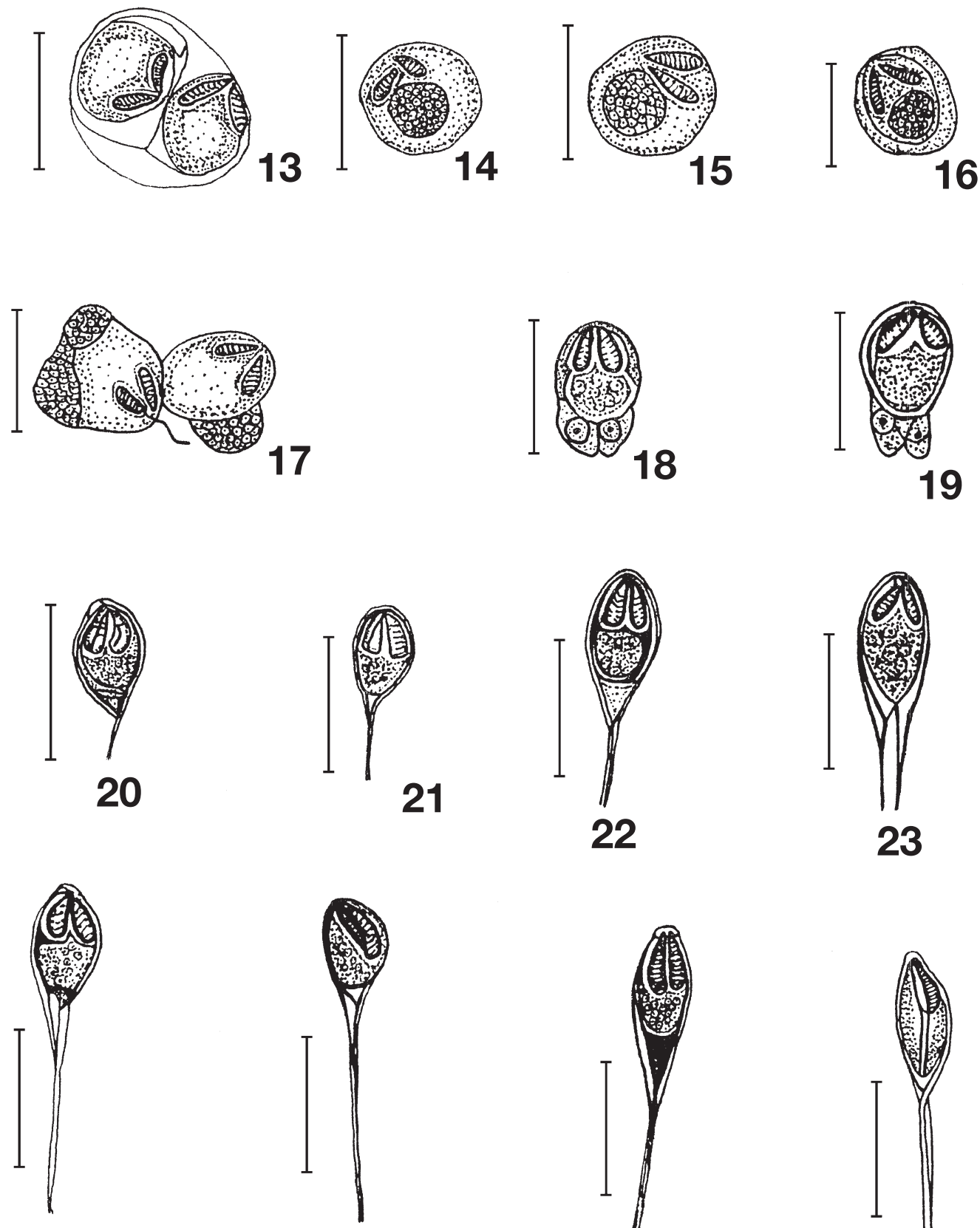

24
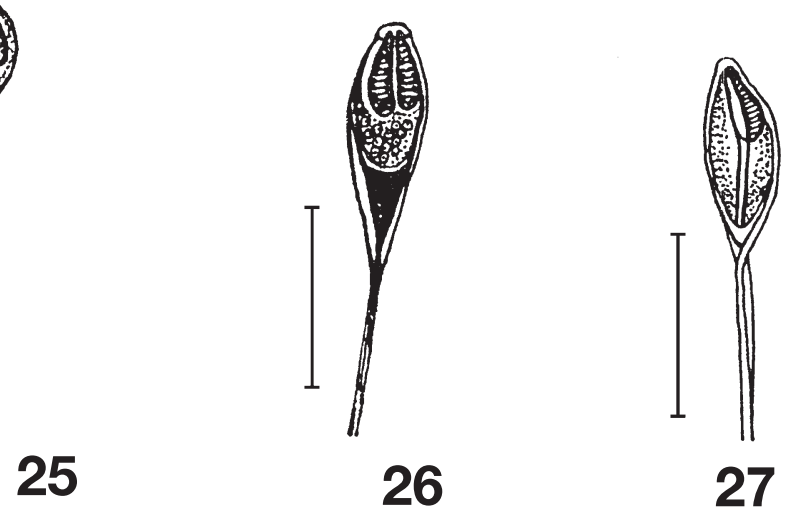

Figs. 13 to 27. Henneguya suprabranchiae. Schematic illustration of immature (Figs. 13 to 25) and mature (Figs. 26 to 27 ) spores infecting intestine of Clarias gariepinus. Figs. 13, 14, 15 \& 17. Stage 1; Fig. 16. Stage 2; Fig. 18. Stage 3; Fig. 19. Stage 4; Fig. 20. Stage 5; Fig. 21. Stage 6; Fig. 22. Stage 7; Fig. 23. Stage 8; Figs. $24 \& 25$. Stage 9; Figs. $26 \& 27$. Stage 10 . (Scale bars $=15 \mu \mathrm{m})$

\section{Histology}

Cysts comprising immature and mature spores were found in the outer layer of the gut wall (Figs. 28, 29 \& 30). The cysts developed in the smooth muscle were covered by the tela subserosa and the serous membrane. Because of their large size, the cysts induced severe alterations such as atrophy of the muscle layer. Thus, the plasmodium was covered by a layer of degenerated smooth-muscle cells. The ectoplasm of the plasmodium consisted of a layer containing the dark-staining nuclei of generative cells, while the plasmodium center was filled with mature spores. 


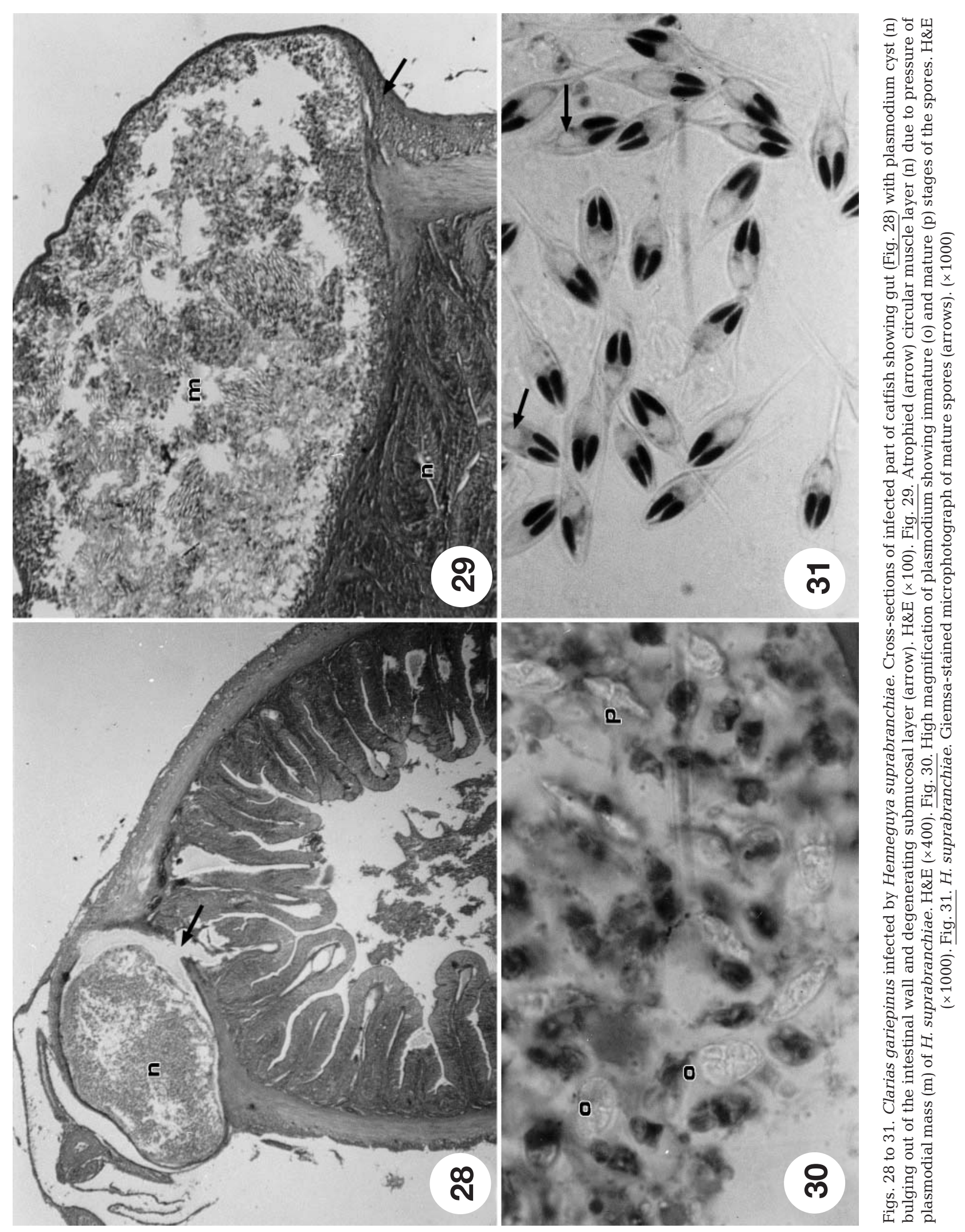




\section{DISCUSSION}

Shape and size are important morphological characteristics in evaluating the degree of spore maturity, since they help to distinguish between variations in size between spores of related species. Therefore, the present study concentrated on documenting changes in shape and size throughout development in immature and mature stages of Henneguya suprabranchiae. The morphometric characteristics of the mature stage were compared to those of other Henneguya species, such as $H$. branchialis (Ashmawy et al. 1989) infecting the suprabranchial organ and gills of Clarias gariepinus in Egypt; $H$. branchialis infecting gills, the secondary respiratory organ and the outer wall of the small intestine of the C. lazera investigated by AbdelGhaffar et al. (1995) in Egypt; and H. nyongensis (Fomena and Bouix, 1996) infecting the gills and muscles of Marcusenius moorii in Cameroun (Table 2).

All the above-mentioned species are classified as Stage 9 in Table 1, since their characteristics, especially their measurements, seem to be most similar to this stage. Thus it would appear that stages of other species described by the cited authors as juvenile or pre-mature stages were in fact mature. Immature stages are mainly round in shape, with oval capsules and short caudal processes, and lack a suture line. Mature spores are elongated, with long, parallel polar capsules and long and slender caudal processes; they have a distinct suture line, and a rounded protrusion at the anterior end (this characteristic may be valuable for taxonomical purposes). Several characteristics do not appear in any of the immature and pre-mature stages (e.g. no suture line in lateral view), while other features are rudimentary or very weakly developed, e.g. the cap-like structure at the anterior pole and the triangular thickening of the sporoplasm base.

Mature spores of Henneguya suprabranchiae are redescribed and compared with those of other African species in Table 2. The spores of $H$. bopeleti (Fomena and Bouix 1987) infecting the gills of Chrysichthys nigrodigitatus in Cameroun differ from the spores in the present study by the larger size of the caudal processes. Despite a similar morphology to $H$. suprabranchiae (Landsberg 1987) infecting the suprabranchial organ of Clarias gariepinus in Israel and H. suprabranchiae isolated from the suprabrachial organ and intestine of the same host in Egypt (Hegazy 1999), the spores in the present study differed in the number of polar filament coils, the suture line and the triangular thickening of the sporoplasm base (e.g. Hegazy [1999] observed 9 to 10 coils vs 8 to 12 turns in the present study). Triangular thickening of the sporoplasm base was also noticed in $H$. ghaffari infecting the Nile perch Lates niloticus in Egypt by Ali (1999). A suture edge and line were also visible in the lateral view of the mature spores of other Henneguya species.

Spore maturity can be completed without cleavage of the pansporoplasm until the final stage is reached and the spores begin to separate (Fig. 11). In some cases such separation occurred at stage 1 resulting in 2 separate spores (Fig. 12).

Henneguya suprabranchiae appears to be a pathogenic species. It induced severe morphological changes in the intestinal wall of the infected portion of the host's gut, which becomes damaged and thickened. Similar symptoms were reported by Ali (1999) in Lates niloticus; he described intestinal plasmodia of $H$. ghaffari inducing atrophy of the intestinal muscularis and leading to significant loss of the muscular capacity of the intestine followed by peritonitis.

On the other hand, the present plasmodia did not invade the intestinal lumen, in contrast to Myxobolus nodulointestinalis described by Masoumian et al. (1996) in Barbus sharpeyi. The large plasmodium masses of Henneguya ghaffari observed by Ali (1999) caused a constriction of the intestinal lumen in Lates niloticus.

In the present study, establishment of the plasmodia in the outer layer of the gut caused severe thickening, damage, and atrophy of large areas of the smooth muscles that could lead to intestinal functional disorders.

Acknowledgements. I thank Dr. A. Badawy for his review of the manuscript. The constructive comments given by 2 anonymous reviewers greatly improved the paper.

\section{LITERATURE CITED}

Abdel-Ghaffar F, El-Shahawi G, Naas S (1995) Myxosporidia infecting some Nile fishes in Egypt. Parasitol Res 81: 163-166

Abolarin MO (1971) A new species of Henneguya (Myxosporidia) from west Africa catfish, Clarias lazera Val., with a review of the genus Henneguya (Thelohan, 1892). Afr J Trop Hydrobiol Fish 1:93-106

Ali MA (1999) Henneguya ghaffari sp. n. (Myxozoa: Myxosporea), infecting the Nile perch Lates niloticus (Teleostei: Centropomidae). Dis Aquat Org 38:225-230

Ashmawy KI, Abou El-Wafa SA, Imam EA, El-Otifi YZ (1989) Description of newly recorded Myxosporidia protozoa of freshwater fishes in Behara Province, Egypt. Assoc Vet Med J 49:43-53

Conn HJ, Darrow MA, Emmel VA (1960) Staining procedures used by the biological stain commission, 2nd edn. Williams and Wilkins Company, Baltimore, MD

Current WL, Janovy J (1978) Comparative study of ultrastructure of interlamellar and intralamellar types of Henneguya exilis Kudo from channel catfish. J Protozool 25:56-65

Drury BAR, Wallington AE (1980) Carleton's histological techniqe, 5th edn. Oxford University Press, Oxford

Fomena A, Bouix G (1987) Contribution a l'étude des Myxosporidies des poissons d'eau douce du Cameroun. III. Espèces nouvelles du genre Henneguya (Thelohan, 1892) et Thelohanellus (Kudo, 1933). Rev Zool Afr 101:43-53 
Fomena A, Bouix G (1996) New species of Henneguya (Thelohan, 1892) (Myxozoa: Myxosporea) parasites of freshwater fishes in Cameroun. J Afr Zool 110:413-423

Fomena A, Bouix G (1997) Myxosporea (Protozoa: Myxozoa) of freshwater in Africa: keys to genera and species. Syst Parasitol 37:161-178

Geoffrey GB, Aimls HT (1978) An introduction to histotechnology. Appleton, Century, Crofts, New York

Hegazy AM (1999) Light and electron microscopic studies on a myxozoan infecting some Egyptian fishes in Bahr Shebin Canal. MSci thesis, Faculty of Science, Menoufia University, Menoufia

Kent ML, Hoffman GL (1984) Two new species of Myxozoa, Myxobolus inquus sp. n. and Henneguya theca sp. n. from the brain of a south American knife fish, Eigenmannia virescens (V). J Protozool 31:91-94

Landsberg JH (1987) Myxosporean parasites of the catfish, Clarias lazera (Valenciennes). Syst Parasitol 9:73-81

Lom J, Arthur JR (1989) A guideline for the preparation of

Editorial responsibility: Wolfgang Körting,

Hannover, Germany species description in Myxosporea. J Fish Dis 12:151-156

Masoumian M, Baska F, Molnàr K (1996) Myxobolus nodulointestinalis sp n. (Myxosporea, Myxobolidae) a parasite on the intestine of Barbus sharpeyi. Dis Aquat Org 24: 35-39

McCraren JP, Landolt ML, Hoffman GL, Meyer FP (1975) Variation in response of channel catfish to Henneguya sp. infections (Protozoa: Myxosporidia). J Wildl Dis 11:2-7

Paperna I (1973) Occurrence of Cnidospora infections in freshwater fishes in Africa. Bull Inst Fr Afr Noire (A Sci Nat) 5:509-552

Paperna I (1996) Parasites infections and diseases of fishes in Africa. An update. CIFA (Common Inland Fish Afr) Tech Pap 31:1-22

Shariff M (1982) Henneguya shaharini sp. nov. (Protozoa: Myxozoa), a parasite of marble goby, Oxyelestris marmoratus (Bleker). J Fish Dis 5:37-45

Thelohan P (1892) Recherches sur les Myxosporidies. Bull Sci Belgium 26:100-394

Submitted: June 15, 2001; Accepted: March 6, 2002

Proofs received from author(s): September 1, 2002 